\title{
A giant intra-abdominal cyst
}

\author{
Pedro Magalhães-Costa, Leopoldo Matos, Cristina Chagas
}

Department of Gastroenterology, Hospital Egas Moniz, Centro Hospitalar Lisboa Ocidental, Lisboa, Portugal

\section{Correspondence to} Dr Pedro Magalhães-Costa, pmagalhaescosta@gmail.com

Accepted 16 January 2015

\section{CrossMark}

\footnotetext{
To cite: Magalhães-Costa $P$, Matos L, Chagas C. BMJ Case Rep Published online: [please include Day Month Year] doi:10.1136/bcr-2014208020
}

\section{DESCRIPTION}

A 52-year-old postmenopausal woman presented to our emergency room (ER) with a 4-year history of a progressive abdominal distension. She did not have a fever, constipation or diarrhoea, vomiting, weight or appetite loss. Her medical history was unremarkable. She was a heavy drinker (calculated at $>300 \mathrm{~g} /$ day of alcohol for over 10 years). On physical examination, she was tachycardic (heart rate $111 \mathrm{bpm})$ but afebrile. She was severely malnourished and had significant muscle mass loss; her abdomen was markedly distended and there was visible collateral venous circulation (figure 1); bowel movements were absent; she had a positive liquid wave signal, however, with lateral decubitus; there was no shifting dullness sign. No peripheral oedema was noted. Laboratory tests revealed a discrete microcytic anaemia with a slightly elevated prothrombin time/international normalised ratio (1.2). Remaining blood analyses were unremarkable, namely serum albumin, bilirubin, $\mathrm{C}$ reactive protein and viral serology (HIV, HBV and HCV negative). An abdominal paracentesis was suggested. However, the patient refused this and she was discharged with diuretics (furosemide and spironolactone). Two days later, she returned to the emergency department with the same symptoms and no improvement with the prescribed diuretics. At this point, it was decided to perform abdominal imaging prior to abdominal paracentesis (figure 2). Ecographically, the presence of a large amount of

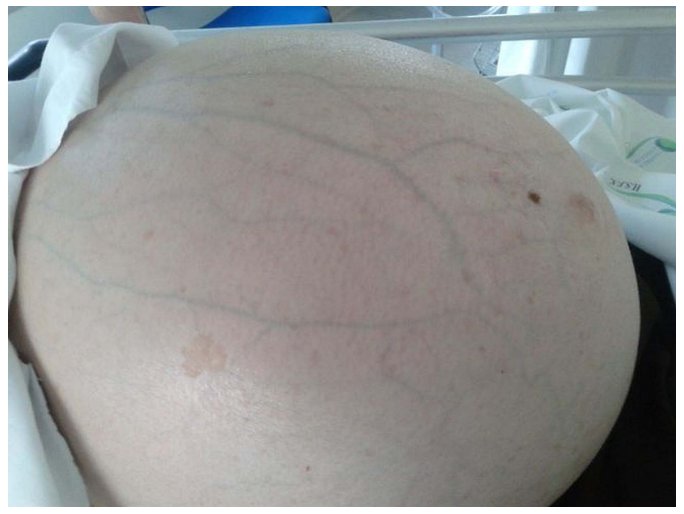

Figure 1 Patient's abdomen: gross abdominal distension and visible collateral venous circulation. intra-abdominal non-pure fluid was noted, and the small bowel was totally collapsed and entrapped against the mesenterium root. CT scan demonstrated a voluminous cystic lesion, measuring $29 \times 37 \times 40 \mathrm{~cm}$ of transversal, anteroposterior and longitudinal diameter, compressing and deviating all the abdominal structures, namely the small bowel, kidneys, liver and stomach. This cystic lesion had thin inner echoes and thin walls, and showed no septations or parietal vegetations. Its probable origin was the right ovary. The patient was then referred for observation to gynaecology, where a surgical approach was recommended; the patient refused surgery and was discharged against medical advice. Giant intra-abdominal cysts have become comparatively rare because of advances in healthcare systems. ${ }^{1}{ }^{2}$ Ovarian cystic lesions are common after the fourth decade of life and, in rare cases, can reach large sizes. ${ }^{13}$ Clinically, they can mimic ascites, thus, before invasive diagnostic procedures (eg, paracentesis) are to be performed, physicians should consider imaging techniques.

\section{Learning points}

When faced with a patient with chronic severe gross abdominal distention, physicians should be aware of the multiple differential diagnosis to be made.

- As demonstrated with this case report, even though the anamnesis and physical exam pointed into a probable new-onset ascites, upon such a scenario, a proper use of abdominal imaging should be sought.

- Currently, giant intra-abdominal cysts mimicking ascites is rare, however, in postmenopausal woman, ovarian cystic lesions can reach large sizes.

- This case illustrates the importance of a proper physical examination (and better performance of the shifting dullness sign over the wave sign in the diagnosis of ascites, as described in the literature ${ }^{4}$, and the consideration of 'pseudoascites' in the differential diagnosis of ascites (in this case, a probable voluminous anexial cyst), especially in women. 

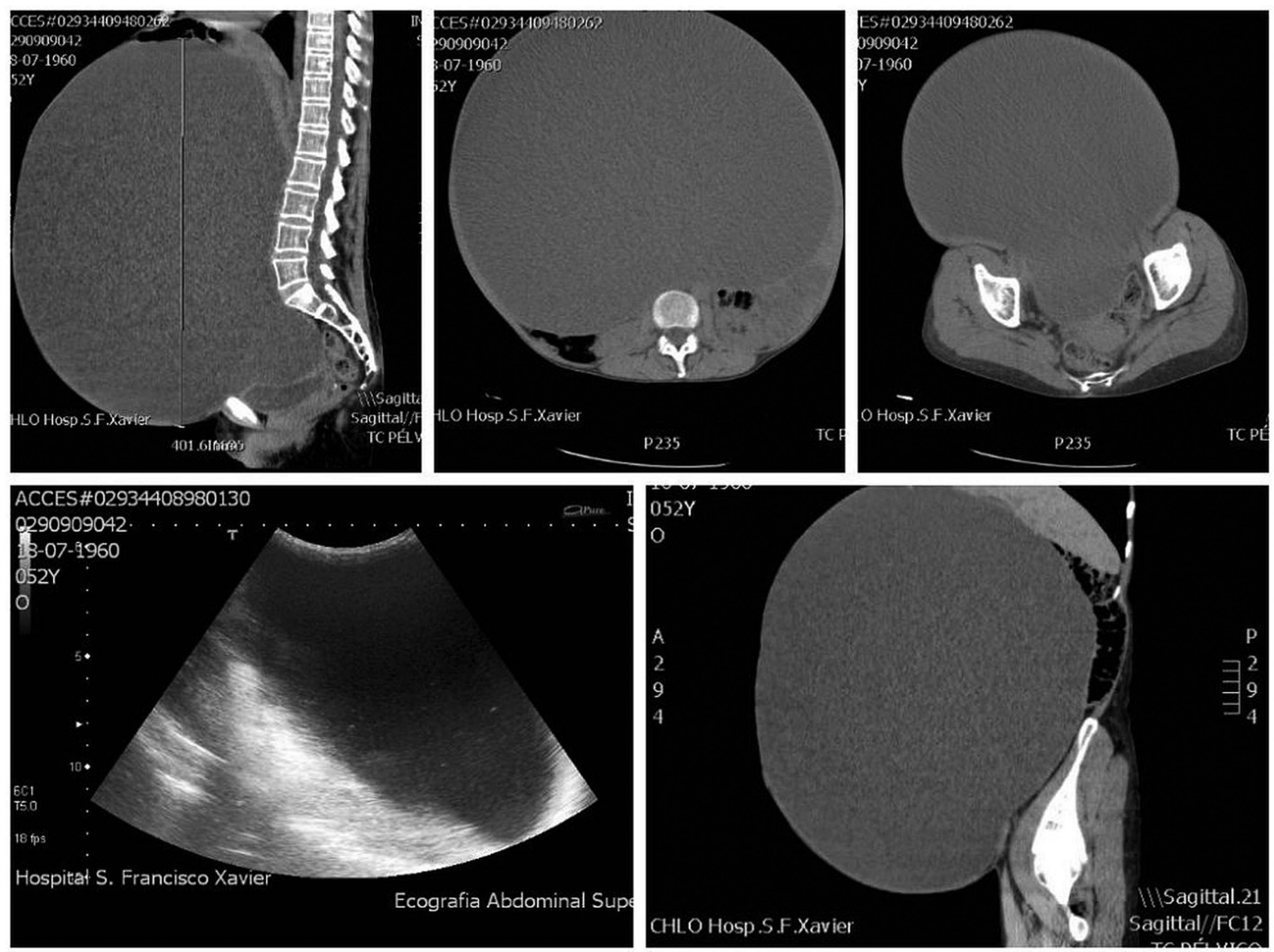

Figure 2 Abdominal ultrasonography (US) and CT: US findings (bottom left) were the presence of free intra-abdominal non-pure fluid, and the small bowel totally collapsed and entrapped against the mesenterium root. CT scan: a voluminous cystic lesion causing a posterior displacement of the bowel loops.

Contributors PM-C treated the patient and wrote the manuscript. LM and CC reviewed the manuscript.

\section{Competing interests None.}

Patient consent Obtained.

Provenance and peer review Not commissioned; externally peer reviewed.

\section{REFERENCES}

1 Menahem S, Shvartzman P. Giant ovarian cyst mimicking ascites. J Fam Pract 1994;39:479-81.

2 Aydinli B, Yildirgan M, Kantarci M. Giant mesenteric cyst. Dig Dis Sci 2006;51:1380-2.

3 Bernal Martínez S, Luna Benítez I, Olivares Valencia CV, et al. Giant cyst of the ovary. Report of a case. Ginecol Obstet Mex 2001;69:259-61.

4 Cattau EL, Benjamin SB, Knuff TE, et al. The accuracy of the physical examination in the diagnosis of suspected ascites. JAMA 1982;247:1164-6.

Copyright 2015 BMJ Publishing Group. All rights reserved. For permission to reuse any of this content visit

http://group.bmj.com/group/rights-licensing/permissions.

BMJ Case Report Fellows may re-use this article for personal use and teaching without any further permission.

Become a Fellow of BMJ Case Reports today and you can:

- Submit as many cases as you like

- Enjoy fast sympathetic peer review and rapid publication of accepted articles

- Access all the published articles

- Re-use any of the published material for personal use and teaching without further permission

For information on Institutional Fellowships contact consortiasales@bmjgroup.com

Visit casereports.bmj.com for more articles like this and to become a Fellow 